\title{
Cataract surgery rate in Mosul city
}

\author{
Amer Y. Rajab \\ Department of Surgery, Collage of Medicine, University of Mosul.
}

(Ann. Coll. Med. Mosul 2008; 34(1): 76-80).

Received: $25^{\text {th }}$ Nov 2007; Accepted: $21^{\text {st }}$ May 2008.

\section{ABSTRACT}

Objective: To compare the number of cataract surgery rate in Mosul to other part of the world and determine the factors that influence this rate.

Methods: case series study from public and private hospitals in Mosul, on patients who had cataract operations during 2001.

Results: Cataract surgery rate was 1098 per 1 million. Only 15.2\% were associated with intraocular lens implant.

Conclusion: Cataract surgery rate in Mosul was the same as in other Middle East Countries, but was very low compared to developed countries.

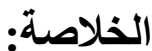

الهدف: لمعرفة عدد عمليات الساد التي تجرى في محافظة نينوى خلال عام واحد والعو امل المؤثرة عليها التصميم: در اسة الحالات المتتالية.

مكان إجراء الدراسة والإطار الزمني لها: جميع مستشفيات محافظة نينوى الرسمية و الخاصة خلال عام I . . ب. المشاركون: جميع المرضى الذين أجريت لهم عملية رفع الساد في عام ا . . ب . النتيجة: تبين أن عدد العمليات التي أجريت في محافظة نينوى خلال عام ا . . ب هي ^9 ـ لكل مليون نسمة. الاستتتاج: هذا العدد من العمليات يشبه ما يجرى في بلدان شرق البحر الأبيض المتوسط ولكنه قليل بالنسبة لما يجرى في الدول المتقدمة. 
$\mathbf{T}$

here are three factors that influence the amount of cataract surgery that is performed in a community; the age structure of the community, the indications or thresholds that are used for surgery, and the proportion of those who need or are eligible for surgery and actually have surgery ${ }^{(1)}$.

These three factors combine to give the overall "cataract surgery rate" (CSR) that has been defined by world health organization (WHO) as the number of cataract operations performed per one million population per year ${ }^{(1)}$. The volume of cataract surgery already had increased dramatically around the world over the past 20 years ${ }^{(2)}$. It increased approximately four folds in just ten years in both the United states and Sweden through the 1980 's ${ }^{(3)}$, and increased three folds in United kingdom over this time ${ }^{(4)}$.

Economically, developed countries usually perform between 4000-6000 cataract operations per million populations per year. India had dramatically increased its CSR in the last ten years from less than 1500 to a figure of around 3000 today $^{(5)}$.In the middle income countries of Latin America and part of Asia as Middle East, the CSR is between $500-2000$ per million per year. In most of Africa, China and the poorer countries of Asia the rate was often less than $500^{(6)}$. The major reasons for low CSR includes: low demand because of fear of surgery, low demand from poverty because of high cost of surgery, low demand because of poor visual results and lack of ophthalmologists particularly in Africa $^{(6)}$.

The aim of this study is to assess the number of cataract operations done in Mosul province, compare it to other parts of the world and to determine the factors, which influence this CSR.

\section{Patients and methods:}

The study was conducted during the period from Jan. 2001 to Jan. 2002. The patients who underwent an operation for cataract at the public as well as the private hospitals were recorded and the data were calculated in relation to age and sex and type of operation.

\section{Results:}

The number of operations done in Mosul hospitals was 2440 (table 1). Mosul population at 2001 was 2222042 (according to health authorities). Therefore, the CSR is 1098 per one million per year. Table 2 shows the distribution of age and sex of patients who had cataract operations. There is three folds increase, from ages 40 's (5.2\%) to 50's (18.2\%), and 2.5 folds from ages of 50's (18.2\%) to ages of 60 's (42.6\%) but it is very low at ages of 80 's (3.7\%). Tow thirds of operations were done in private hospitals. 
Table (1): The numbers of cataract operations done in each hospital during Jan. $1^{\text {st }}$. Dec. $31^{\text {st }}$. 2001.

\begin{tabular}{|c|c|}
\hline Hospital clinic & Total \\
\hline Public: $\quad$ Al-Salam & 563 \\
\hline Al-Jumhori & 224 \\
\hline Talafar & 92 \\
\hline Private: $\quad$ Al-Zahrawi & 100 \\
\hline Al-Rahma & 120 \\
\hline Ibn-Biatar & 141 \\
\hline Al-Sabah & 450 \\
\hline Al-Rabee` & 750 \\
\hline Total & 2440 \\
\hline
\end{tabular}

Table (2): Age and sex distributions of cataract surgery during 2001 in Mosul.

\begin{tabular}{||c|c|c|c||}
\hline Age & $\begin{array}{c}\text { Male } \\
\text { no. \& } \%\end{array}$ & $\begin{array}{c}\text { Female } \\
\text { no. \& } \%\end{array}$ & Total \\
\hline$<40$ & $120(4.9 \%)$ & $45(1.8 \%)$ & $165(6.7 \%)$ \\
\hline $40-49$ & $51(2.1 \%)$ & $76(3.1 \%)$ & $127(5.2 \%)$ \\
\hline $50-59$ & $105(4.3 \%)$ & $345(14.1 \%)$ & $450(18.4 \%)$ \\
\hline $60-69$ & $370(15.2 \%)$ & $668(27.4 \%)$ & $1037(42.6 \%)$ \\
\hline $70-79$ & $247(10.1 \%)$ & $323(13.2 \%)$ & $570(23.3 \%)$ \\
\hline $80--$ & $53(2.2 \%)$ & $37(1.6 \%)$ & $2440(100 \%)$ \\
\hline Total & $946(39 \%)$ & $1494(61 \%)$ & \\
\hline
\end{tabular}

Table (3): The number of operations done in public and private hospitals during 2001

\begin{tabular}{|c|c|}
\hline Hospitals and clinics & Number of operations \\
\hline Public hospitals & $\mathbf{8 7 0}(35.7 \%)$ \\
\hline Private hospitals & $1570(64.3 \%)$ \\
\hline Total & $2440(100 \%)$ \\
\hline
\end{tabular}

Table (4) : The type of cataract operations done.

\begin{tabular}{|c|c|}
\hline Type of cataract operations & The number of operations \\
\hline ICCE and ECCE & $2070(84.8 \%)$ \\
\hline ECCE and IOL implant & $370(15.2 \%)$ \\
\hline Total & $2440(100 \%)$ \\
\hline
\end{tabular}

ICCE = Intra-capsular cataract extraction. ECCE=Extra-capsular cataract extraction. IOL=Intra-ocular lens 


\section{Discussion:}

The volume of cataract surgery already has increased dramatically around the world over the past 20 years, especially in USA, Sweden and UK $(2,3,4)$. While it remained low in Eastern Mediterranean countries $^{(7)}$, which is around 1000 as estimated by Allen Foster in $1997^{(6)}$. In our study the CSR was 1098 which is similar to countries in Middle East but very low compared to developed countries as in Australia 6800, USA 5700 and UK $2700^{(8)}$ while in India 3100, South-east Asia 2400, Africa 300 and China $280^{(6)}$. This low rate was due to many causes. Age is one important factor in increasing surgery rate in developed countries, which was doubled with each decade until every second person in their 90s would have cataract surgery ${ }^{(9)}$. This is due to the increase in life expectancy in the last few decades in most countries (6). Nevertheless, this is not the case in our study, because we did not find patients in their 90 s and few in their $80 \mathrm{~s}(3.8 \%)$, who rarely visit ophthalmologist, or due to neglect, as in Africa ${ }^{(5)}$.

Threshold or indication of surgery was the other reason which lowers the CSR in our study because for generation till now the threshold was set as bilateral blindness due to low health education of community and not good quality of our surgery. As shown in this current study, only $15 \%$ of cataract surgery was with IOL implantation and the rest was ICCE or ECCE in which the quality of vision with aphakic correction did not justify earlier surgery $^{(3)}$. While modern intraocular lens provide excellent visual rehabilitation in almost every instance and the acuity thresholds has tumbled from $6 / 60$ to $6 / 24$ then $6 / 18$ and is now often $6 / 9$ or less ${ }^{(10)}$. The number of cataract operations increased 2.5 time as the visual acuity criterion changed from less than $6 / 60$ to less than $6 / 24$ and five folds if it goes to less than $6 / 12^{(11)}$.

Surgical coverage was the most important factor in lowering CSR in our hospitals due poor services, especially in public hospitals (only $35.7 \%$ of the work), but even where such facilities are available there was often lack of instruments and other equipments exacerbated by poor maintenance, with medication and other consumables in short supply.

\section{Conclusion:}

CSR was the same as in the surrounding Middle Eastern countries but was lower than other developed countries due to neglect in old patients. The indication of operation is still for blind eye and, due to lack of surgical resources.

\section{References:}

1. World Health Organization; Global initiative for elimination of avoidable blindness. An informal consultation of avoidable blindness. An informal consultation WHO/PBI 97, 61 Geneva; WHO, 1997.

2. Stork WJ, Sommer A, Smith RE. Changing trends in intraocular lens implantation. Arch Ophthalmology 1989; 107: 1441-4. 
3. Norregaard JC, Bernth-Petersen $P$, Andersen TF. Changing threshold for cataract surgery in Denmark between 1980 and 1992 Acta Ophthalmol. Ophthalmology 1996; 74: 604-8.

4. Williams ES, Seward HC: Cataract surgery in South West Thames Region: an analysis of age-adjusted surgery rates and length of stay by district. Public Health 1993; 107: 441-9.

5. The World Health Report: Life in the $21^{\text {st }}$. century, a vision for all WHO. Geneva, 2000 Page 47.

6. Foster A. Vision 2020: The cataract challenge. Community Eye Health Journal 2000 Vol.13 No.34, PP. 17-19.

7. Thylefors $B, \quad$ Negrel AD, Pararajasegaram R, et al., Global data on blindness. Bull World Health Organ. 1995; 73: 115-21.
8. Sletteberg O, Hovding G, Bertelsen T. Do we operate too many cataracts? Acta Ophthalmology. Scand 1995, 73: 77-80.

9. MacCarty CA, Keeffe JE, Tayler HR. The need for cataract surgery projections based on lens opelity. Visual acuity and personal concern. Br. J. Ophthalmology. 1999; 83: 62-5.

10. Klein BEK, Klein R, Moss SE, Incident cataract surgery. The Beaver Dam Eye Study. Ophthalmology 1997; 104: 57380.

11. Cataract Management Guidline Panel. Cataract in adults, management of functional impairment. Clinical practice guideline, Number 4. AHCPR Pub No 93-0542. Rockville; MD. Public Health Service, Agency for Health Care Policy and Research, February 1993. 